\title{
La importancia de los estudios epidemiológicos en las colonias de abejas melíferas (Apis mellifera) en la península de Yucatán, México
}

J. Selva Andina Anim. Sci. 2018; 5(1):1-2.

La epidemiología, estudia los eventos relacionados con la salud y la aplicación de estos estudios para el control de enfermedades en las poblaciones, su importancia en la "actividad apícola" radica actualmente en la detección de numerosas enfermedades, plagas que afectan la sanidad de colonias de abejas melíferas (Apis mellifera L.). En este sentido, varroosis, causada por un ácaro (Varroa destructor), considerado como principal problema sanitario, afectando la apicultura a nivel mundial, nosemosis, causada por hongos (Nosema apis y $N$. ceranae), se ha incrementado notoriamente su distribución, prevalencia a nivel mundial. Recientemente aethinosis o etinosis, causada por el coleóptero nitidúlido (Aethina tumida), distribuida en diversos países del continente Americano, ocasionando pérdidas económicas, a ello se suma la presencia de diversos virus que afectan a poblaciones de abejas melíferas.

Es importante señalar que una enfermedad se presenta al existir condiciones propicias para su desarrollo, de ahí que se hace necesario establecer los factores de riesgo que contribuyen su presencia, lo que permitirá reducir los niveles de infección o infestación en las colonias, con el fin de reducir o evitar pérdidas económicas. Valorar la fluctuación, dinámica poblacional de un agente causal a lo largo de su ciclo anual, ayudaría a intervenir en los periodos de incremento. Por ejemplo, en la península de Yucatán (PY), México, los niveles de infección por nosemosis, está en los meses de mayor precipitación pluvial (septiembre y octubre), al igual que la ascosferosis, causado por el hongo Acosphaera apis.

Por otro lado, la presencia de un agente etiológico, se hace necesario conocer la relación que existe entre las variables ambientales (ej., temperatura, precipitación pluvial, humedad, etc.) la disponibilidad alimenticia natural o artificial (energética y/o proteica), así, se ha observado que la cantidad de individuos de A. tumida en el interior de la colmena durante el periodo de mayor flujo de néctar (marzo-mayo), se reduce debido a la fortaleza que poseen las poblaciones de abejas melíferas.

La genética de las especies juega un rol importante, permite contrarrestar el daño causado por algunas enfermedades, en la PY se cuenta con la presencia de abejas africanizadas (cruza de la subespecie africana con diversas subespecies de origen europeo) y hasta el momento aun con la presencia de A. tumida no se han registrado pérdidas económicas, como las ocurridas en los Estados Unidos atribuidas a A. tumida.

El estrés también puede considerarse como un factor predisponente, se ha observado que las colonias de abejas que son sometidas a condiciones de estrés presentan una mayor susceptibilidad a los agentes infecciosos, que 


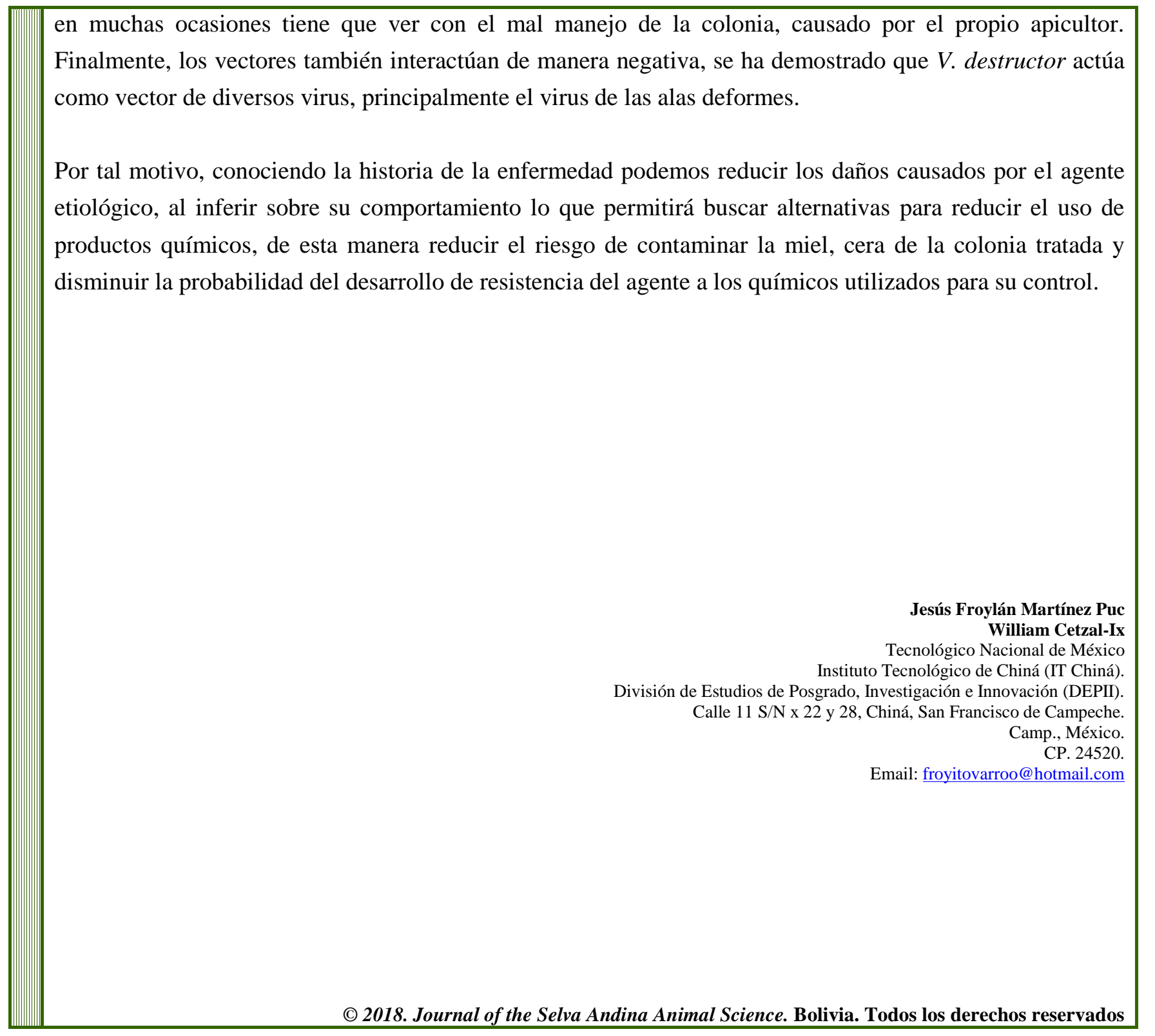

